\title{
Organization and Fine Structure of a Pacemaker Derived from Fetal Rat Myocardium
}

\author{
WENNING QIN, CANDACE G. WOODS, JOEL A. SCHNEIDER, AND W. T. WOODS, JR. \\ Prairie Education and Research Cooperative and Department of Pharmacology, Southern Illinois \\ University School of Medicine, Springfield, Illinois 62701
}

\begin{abstract}
A6.6. precursor cells become committed to the cardiocyte phenotype. Certain of these are believed to specialize further into pacemaker cardiocytes. By culturing explanted embryonic ventricles into in vivo organ culture (Tucker DC, Snider C, Woods WT Jr: Pediatr Res 23:637-642, 1988), we observed pacemaker cells arising apparently from cardiocytes. We hypothesized that this event can be triggered by intercellular attachments, innervation, vascularization, or other factors. The present study was designed to test the hypothesis that primitive ventricular cells in the tubular heart can organize into an anatomically and electrophysiologically distinct pacemaker structure in the absence of innervation or vascularization from extrinsic sources. Developing ventricles of tubular hearts from 10-d-old rat embryos $(n=22)$ were excised and incubated in culture dishes. Within each explant, a group of
\end{abstract}

In the developing mammalian heart, cells committed to the cardiocyte phenotype appear early, and they are initially quiescent $(1,2)$. At a later unknown point in development, some of these cells acquire the pacemaker phenotype. The sequence of steps between quiescent cardiocyte and spontaneously beating cardiocyte are poorly understood. This laboratory reported that 12-d-old rat ventricles explanted and cultured in oculo were quiescent in culture for $4 \pm 1 \mathrm{~d}$. Then spontaneous beating began, and a pacemaker locus was observed at the point of contact between cardiac tissue and the host iris (3). Growth of blood vessels, nerves, extracellular matrix, or iris tissue from the host into the explants was postulated as potential stimuli for organization of the new pacemaker. Pacemaker cells in the new center resembled those of the immature mammalian sinus node and atrioventricular node (4), suggesting that they might be precursors of the cardiac conduction system.

In the present study, influences of extrinsic blood vessels, nerves, and iris tissue were eliminated by explanting embryonic rat ventricles into culture dishes instead of anterior eye

Received November 30, 1993; accepted November 14, 1994.

Correspondence: W. T. Woods, Jr., Ph.D., Prairie Education and Research Cooperative, 326 North Seventh St., Suite 101, Springfield, IL 62701.

Supported by National Institutes of Health Grant HL42258 (W.T.W.) and a grant from the American Heart Association Illinois Affiliate (W.Q.). cells organized into a uniform cluster (diameter, $150 \pm 50 \mu \mathrm{m}$ ) after $8 \pm 2 \mathrm{~d}$ in culture. These cells resembled immature conduction system cells and had electrophysiologic features similar to those of mature pacemaker cells. Single-cell action potentials and impulse conduction patterns proved that the pacemaker cluster was the dominant pacemaker for the entire explant. These results confirm that, in the absence of extrinsic nerves and blood vessels, culture of the tubular ventricle elicits formation of an organized pacemaker, resembling the mature cardiac pacemaker and suggesting that contact with the culture dish surface or some other factor triggers conversion of cardiocytes to the pacemaker phenotype. (Pediatr Res 37: 283-288, 1995)

dpc, days postconception chambers. Emergence of pacemaker activity in the explants followed the same time course observed in the in oculo culture system. A stable rate of firing was achieved simultaneously with formation of a regularly beating cluster of cells best observed at the site of contact between cardiac tissue and culture dish. Action potential recordings confirmed this cluster was the pacemaker for the cultured explant. Electron microscopic examination confirmed the cluster's fine structural similarity to the developing cardiac conduction system.

\section{METHODS}

\section{Tissue Culture}

Four pregnant female rats (Sprague-Dawley), 10-14 wk old and weighing 200-250 g when mated, were provided by Charles River Laboratories (Wilmington, MA). The ages of cardiac explants are reported in dpc (5), with $0 \mathrm{dpc}$ as the day the vagina contained a mucus plug.

After decapitation of pregnant rats, embryos were removed from left and right uterine horns and placed in $37^{\circ} \mathrm{C}$ Hanks' balanced salt solution (GIBCO, Grand Island, NY). Twentytwo 10-dpc hearts were tubular in shape, with truncusconus arteriosus, ventricular outlet, ventricular inlet, and atrial regions separated by constrictions. They were explanted into 35-mm tissue culture dishes (Falcon, Becton Dickinson, Ox- 
nard, CA) containing $2 \mathrm{~mL}$ of Medium 199 (GIBCO) with Earle's salts supplemented with $25 \mathrm{mM} \mathrm{N}$-2-hydroxyethylpiperazine- $N^{\prime}$-2-ethanesulfonic acid buffer, $2 \mathrm{mM} \mathrm{L-}$ glutamine, $20 \mu \mathrm{g} / \mathrm{mL}$ gentamicin, $100 \mathrm{U} / \mathrm{mL}$ penicillin, 100 $\mu \mathrm{g} / \mathrm{mL}$ streptomycin, and 5\% fetal bovine serum ( $\mathrm{pH}$ 7.4). These were maintained at $37^{\circ} \mathrm{C}$ in an atmosphere of $5 \% \mathrm{CO}_{2}$, 95\% air, and $95 \%$ humidity by incubator (Forma Scientific, Marietta, $\mathrm{OH})$. Culture medium was replaced daily. Tissue culture dishes were made of polystyrene with a positively charged surface to promote attachment $(6,7)$.

Cultured explants were observed with a phase-contrast microscope (Nikon, Tokyo, Japan) and recorded on video tape (model C2400, Hamamatsu Photonics K.K., Tokyo, Japan). The widest dimension of the explant $(784 \pm 59 \mu \mathrm{m})$ was at the ventricular inlet-outlet area. For all morphologic measurements, analysis of variance was used to test for statistical significance $(p<0.05)$.

\section{Electrophysiology}

Transmembrane potential recording. Capillary tubing (borosilicate, $2.0 \mathrm{~mm}$ outside diameter, $0.7 \mathrm{~mm}$ inside diameter, Frederic Haer, Brunswick, ME) was pulled on a two-stage puller (Stoelting, Wood Dale, IL), and lumens were filled with $3 \mathrm{M} \mathrm{KCl}$ to provide tip resistances of $20 \pm 10$ megohms. The transmembrane potential recording system (8) included a microelectrode, a microprobe system (KS-700, MPI WP Instruments, Inc., Hawden, CT), and a two-channel 20-MHz digital storage oscilloscope (OS1420, Gould, Hainault, Essex, England). Transmembrane potential and its differentiated signal (change in voltage with respect to time) were photographed with a Polaroid camera. The $t$ test was used to test for statistical significance $(p<0.05)$.

Impulse conduction pattern. Impulse conduction pattern was assessed with dual microelectrodes recording transmembrane potentials and/or unipolar electrograms (9). The intervals (in milliseconds) between the upstrokes of action potentials and the fastest deflections of the electrograms were plotted to reveal impulse conduction patterns.

\section{Electron microscopy}

Explants were grown on collagen membranes (Cellagen, ICN, Cleveland, $\mathrm{OH}$ ), marked for orientation during sectioning with a slit on each side of the explant mass in the layer of cells growing outward from it, and fixed at $25^{\circ} \mathrm{C}$ in $1 \%$ paraformaldehyde- $1.25 \%$ glutaraldehyde in sodium cacodylate buffer for $12 \mathrm{~h}$. They were then washed in sodium cacodylate buffer for $10 \mathrm{~min}$ and postfixed at $25^{\circ} \mathrm{C}$ for $1 \mathrm{~h}$ in $1 \%$ osmium tetroxide. They were then rinsed for $10 \mathrm{~min}$ in sodium cacodylate and dehydrated in increasing concentrations of ethanol (30\%, 50\%, 70\%, 85\%, 95\% twice, and $100 \%$ three times) each for $10 \mathrm{~min}$ at $25^{\circ} \mathrm{C}$. They were infiltrated with Spurr (10) (ethanol-Spurr, 1:1, 1:2, 1:3, and 0:1) each for $3 \mathrm{~h}$ and then polymerized at $60^{\circ} \mathrm{C}$ for $72 \mathrm{~h}$. Thin sections (30-70 nm) were cut on an ultramicrotome (Sorvall MT2-B, Du Pont, Wilmington, DE) with a diamond knife and collected on polyvinyl formate-coated grids. The grids were stained with $2 \%$ uranyl acetate in $50 \%$ methanol, followed by Reynolds' lead citrate
(11). Sections were examined with a Hitachi H-7000 electron microscope (NSA Hitachi, Mountain View, CA) operating at $75 \mathrm{kV}$. Cell sizes were recorded at the widest cell profiles. The nucleus-to-cytosol ratios were expressed as width of nucleus/ (width of cell minus width of nucleus).

\section{RESULTS}

\section{Contraction Rate and Cluster Formation}

Figure 1 shows contraction rates of ventricular explants (including inlet and outlet segments) isolated from embryos at $9,10,11,12$, and $13 \mathrm{dpc}$. Temporal trends in firing rate were similar for each of the five age groups. Because the 9-dpc explants became detached by $\mathrm{d} 16$, later observations were not possible. Firing rates decreased progressively for $5 \mathrm{~d}$ and then increased progressively until the 11 th $\mathrm{d}$ after explantation. To illustrate the observation that cultured atrial and ventricular explants differed in firing patterns, Figure 2 shows contraction rates of atrial explants (left atria, Fig. $2 A$; right atria, Fig. $2 B$ ). Left atrial rates decreased progressively, and right atrial rates increased progressively.

Figure 3 shows a cluster of cells $(150 \pm 50 \mu \mathrm{m}$ in diameter $)$ as it typically appeared in ventricular explants after $8 \pm 2 \mathrm{~d}$ in culture. Distinct clusters were observed (under phase contrast) in 25 of the 48 explants grown on collagen membranes and all of the 41 explants grown on culture dish floors. By the 20th d, clusters grew to $300 \pm 50 \mu \mathrm{m}$ long and $150 \pm 50 \mu \mathrm{m}$ wide; their bases were in contact with the dish floor (Fig. 4). Figure 5 illustrates that after processing with Karnovsky's fixative and $1 \% \mathrm{OsO}_{4}$, the cluster was stained darkly compared with surrounding tissue $(n=10)$.

\section{Action Potentials and Conduction in the Explant}

Figure 6 shows action potentials recorded after 3 wk in culture $(n=7)$. The phase of relatively slow spontaneous depolarization characteristic of pacemaker cells (phase 4 depolarization) was observed only in the cluster area (see Table $1)$. Cells in the clusters had lower $(p<0.05)$ action potential

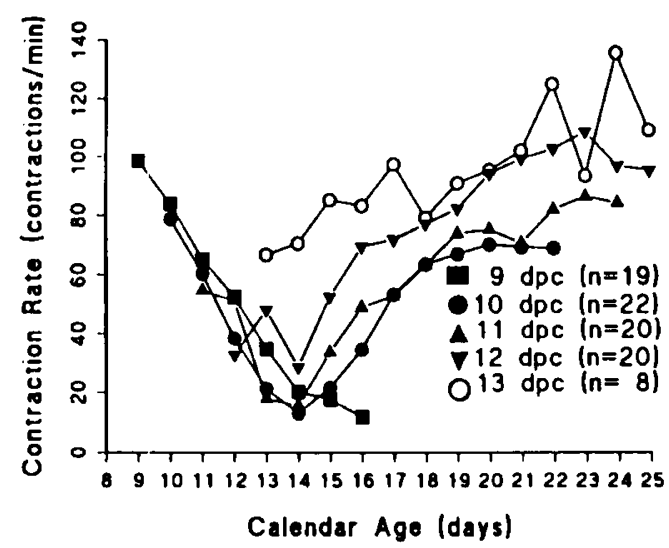

Figure 1. Rates (contractions per minute) of ventricular explants $(9,10,11$, 12 , and $13 \mathrm{dpc}$ ) are plotted against calendar ages (days). Each symbol represents a group of explants placed in culture on a designated day. The 9-dpc rates were counted up to calendar age $16 \mathrm{~d}$, after which they became detached and could not be observed. 
A

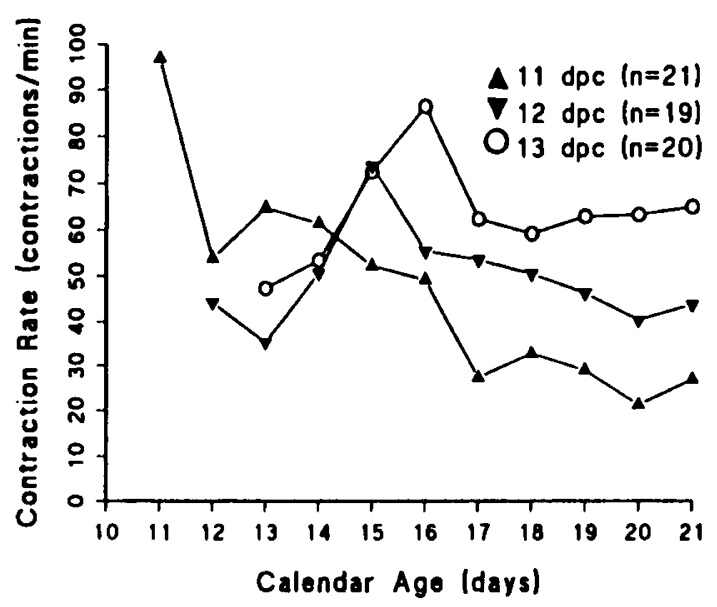

B

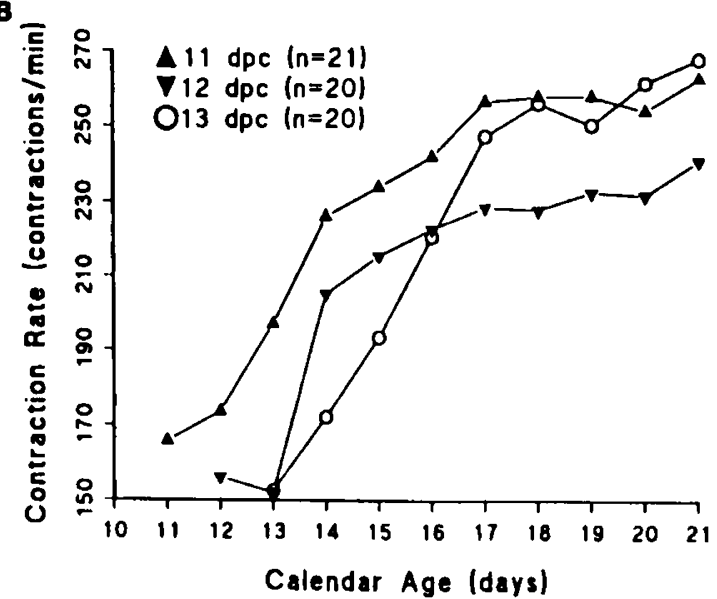

Figure 2. Rates (contractions per minute) of the left $(A)$ and right $(B)$ atrial explants are plotted against calendar ages (days).

amplitudes $(57 \pm 14 \mathrm{mV})$ than noncluster cells $(78 \pm 10 \mathrm{mV})$. Increased firing rates during impalement (cycle length, $701 \pm$ $269 \mathrm{~ms}$ ) caused shortening of action potential duration at $50 \%$ repolarization to $96 \pm 42 \mathrm{~ms}$. Figure 7 illustrates impulse spread through the explant $(n=10)$ at a velocity of $5 \pm 4$ $\mathrm{mm} / \mathrm{s}(n=32)$. Figure 8 illustrates partitioning of explants into pieces. Only the pieces containing the cluster continued to fire at the original rate $( \pm 10 \%)$, whereas all other pieces slowed and became quiescent within $5 \mathrm{~min}$.

\section{Organization and Ultrastructure of the 10-dpc Explant}

Before attachment. After dissection and before attachment to the culture dish, the characteristic cell type of the tubular ventricle was $20 \pm 5 \mu \mathrm{m}$ long, $10 \pm 2 \mu \mathrm{m}$ wide, and contained one centrally located nucleus with one or two nucleoli. The cytoplasm contained free ribosomes, rough endoplasmic reticulum, and contractile filaments organizing into sarcomeres (data not shown). Other cell types included some resembling vascular endothelial cells (see Ref. 12) $(25 \pm 5 \mu \mathrm{m}$ long, $5 \pm$ $2 \mu \mathrm{m}$ wide; one nucleus with one nucleolus; data not shown) and those resembling erythroblasts $(8 \pm 2 \mu \mathrm{m}$ diameter; one nucleus containing clumps of condensed heterochromatin; data not shown).

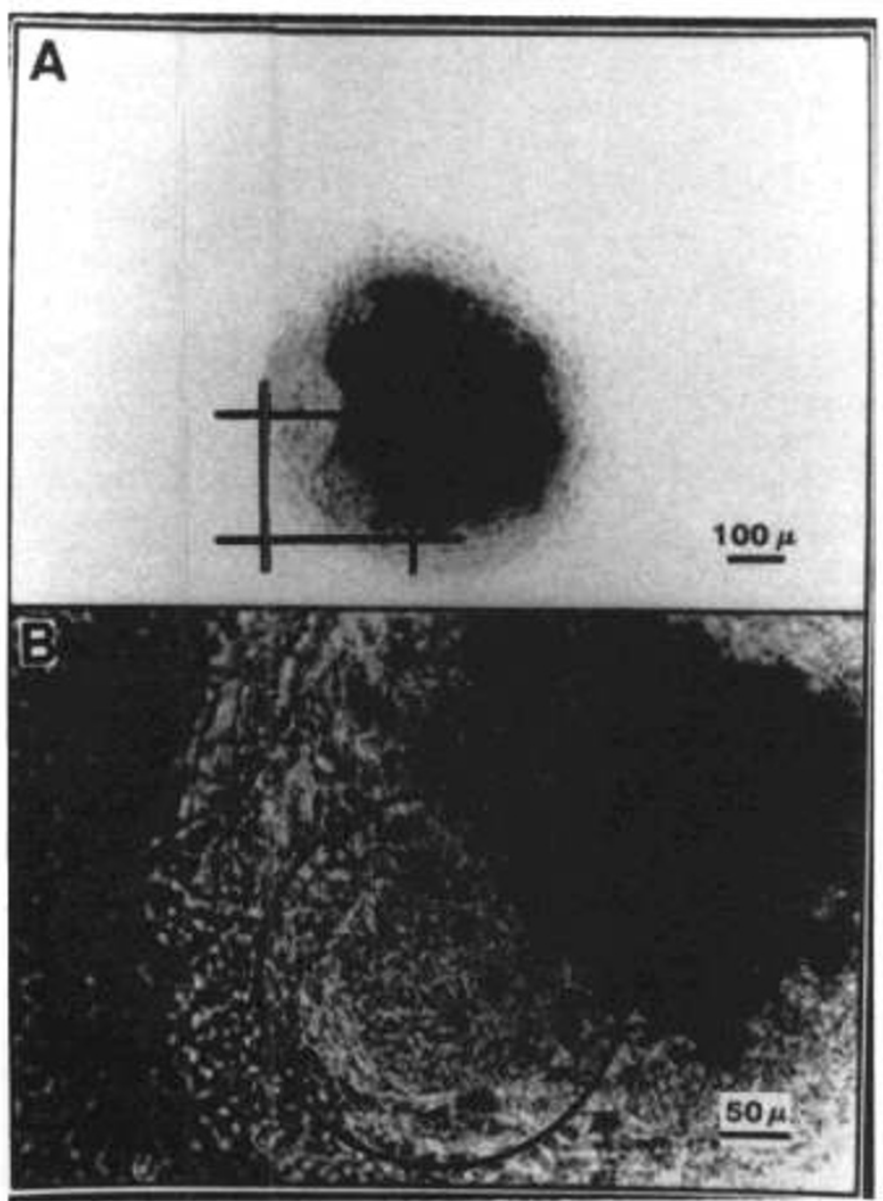

Figure 3. $A$, Ventricular explant $(10 \mathrm{dpc})$ on the 10 th day in culture. A monolayer surrounded the explant (darkest mass) and the cluster was located at the left (inset). Bar, $100 \mu \mathrm{m}$. B, Enlargement of the inset with a shift in focal plane shows it to be a densely packed cell mass enclosed by a filamentous capsule (circle). Bar, $100 \mu \mathrm{m}$.

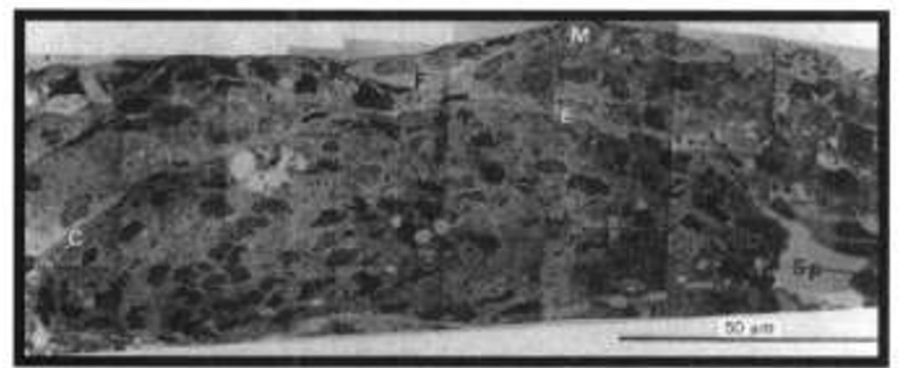

Figure 4. Photo montage of electron micrographs from a section through the cluster of a ventricular explant $(10 \mathrm{dpc})$ on the 28 th day in culture. A layer of mesothelial cells $(M)$ and fibroblasts $(F)$ covered the explant. The cluster of cells was separated from the surrounding area by a space $(S P)$ occupied by several layers of cytoplasmic processes $(C)$ and a layer of endothelial cells $(E)$. Bar, $50 \mu \mathrm{m}$.

After attachment. Within $10 \mathrm{~h}$ after the ventricular explant attached to the culture dish surface, cells with the appearance of migrating endothelial cells grew outward from the explant to form a layer of polygonal mononuclear cells $(50 \pm 10 \mu \mathrm{m}$ long and $35 \pm 10 \mu \mathrm{m}$ wide). Figure 4 shows the new cluster of cells revealed by transmission electron microscopy in each such explant $(n=5)$, revealing a cluster of cells that was not observed in fresh tubular ventricles. The cluster $(150 \pm 50 \times$ $80 \pm 20 \mu \mathrm{m})$ was surrounded by explant tissue except at points 


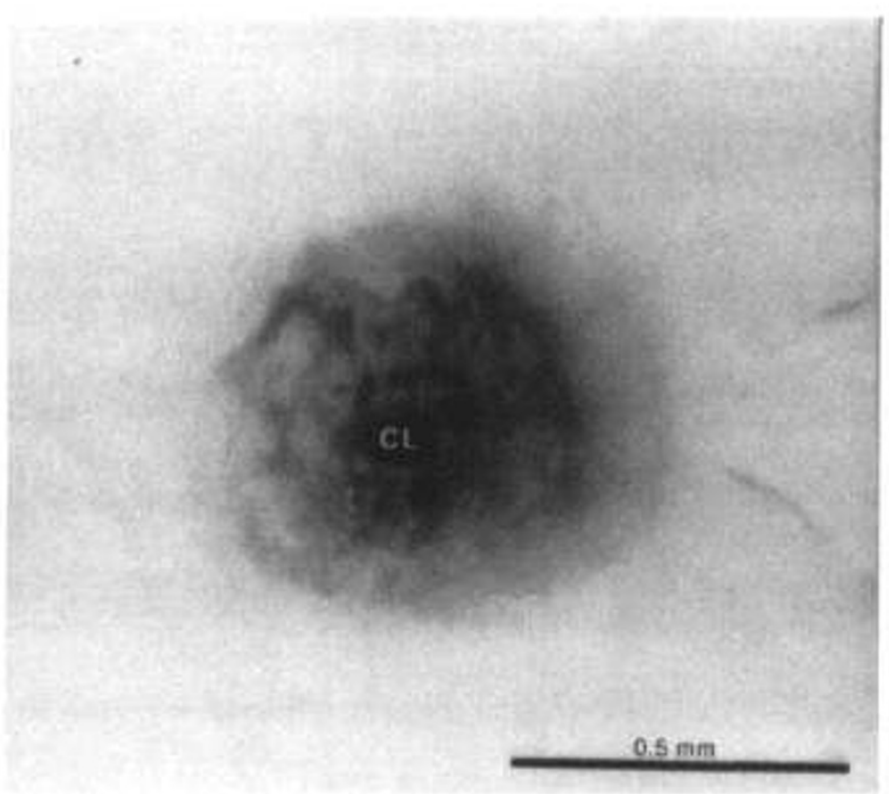

Figure 5. The cluster $(C L)$ is shown after the explant was treated with Karnovsky's fixative, postfixed with $1 \% \mathrm{OsO}_{4}$, and embedded in the Spurr medium.
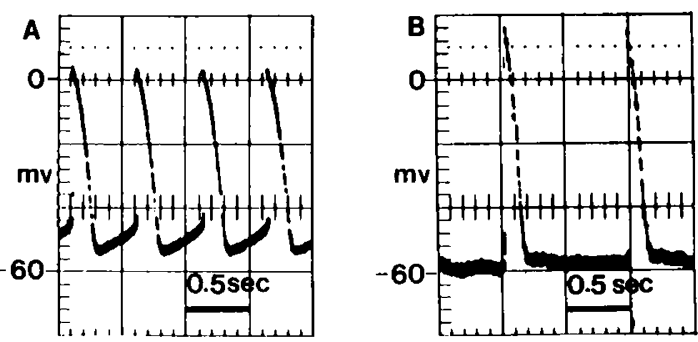

Figure 6. Transmembrane potentials recorded from cells in the cluster $(A)$ and the surrounding tissue $(B)$ of a ventricular explant $(10 \mathrm{dpc})$ on the $23 \mathrm{rd}$ day in culture. Data are summarized in Table 1.

Table 1. Transmembrane potentials (mean $\pm S D$ ) recorded inside (cluster) and outside (noncluster) explant clusters

\begin{tabular}{lccc}
\hline & Noncluster $(n=7)$ & Cluster $(n=7)$ & $p$ \\
\hline Diastolic depolarization & No & Yes & \\
APA $(\mathrm{mV})$ & $78 \pm 10$ & $57 \pm 14$ & $<0.05$ \\
MDP $(\mathrm{mV})$ & $-68 \pm 12$ & $-55 \pm 13$ & $>0.05$ \\
OS $(\mathrm{mV})$ & $11 \pm 3$ & $3 \pm 3$ & $<0.05$ \\
$\mathrm{~V}_{\max }(\mathrm{v} / \mathrm{s})$ & $6 \pm 3$ & $5 \pm 3$ & $>0.05$ \\
CL $(\mathrm{ms})$ & $1315 \pm 387$ & $701 \pm 269$ & $<0.05$ \\
APD $_{50}(\mathrm{~ms})$ & $122 \pm 32$ & $96 \pm 42$ & $>0.05$ \\
\hline
\end{tabular}

APA, action potential amplitude; MDP, maximum diastolic potential; OS, overshoot; $\mathrm{V}_{\max }$, maximum upstroke velocity; $\mathrm{CL}$, cycle length; $\mathrm{APD}_{\mathbf{5 0}}$, action potential duration at $50 \%$ repolarization. When cluster cells were impaled, contraction rate increased (CL decreased).

of contact with the dish surface. It was densely packed with polyhedral cells (diameter, $7.5 \pm 2.5 \mu \mathrm{m}$ ) connected to each other mainly by undifferentiated membrane appositions. Few fasciae adherens and maculae adherens were observed.

Figure 9 shows the clusters' majority cell type, which contained one centrally located nucleus with smooth, regular margins and clumps of condensed heterochromatin. The cytoplasm contained glycogen granules, small mitochondria with multiple cristae, and organizing sarcomeres associated with Z-line material. Large cytoplasmic regions were organelle-free.

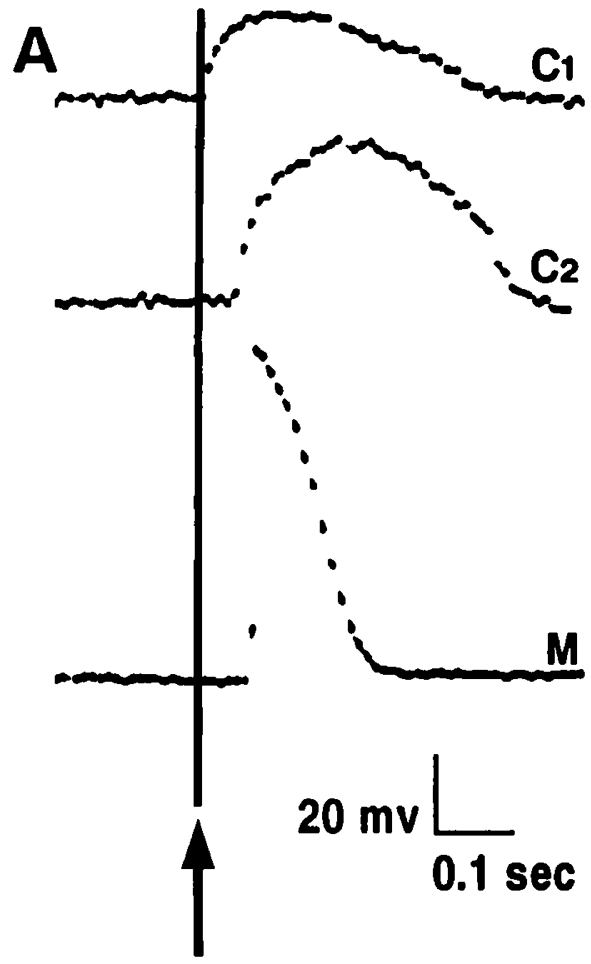

B

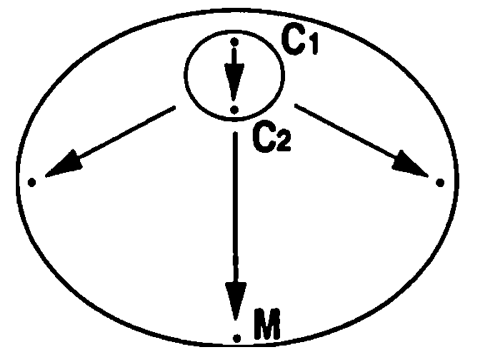

Figure 7. Impulse conduction pattern of a ventricular explant $(10 \mathrm{dpc})$ is shown on the 31st day in culture. $A$, Recordings from points $\mathrm{C}_{1}, \mathrm{C}_{2}$, and $\mathrm{M}$ of the explant (shown in $B$ ) have arrows that mark the time at which point $C_{1}$ was excited. $B$, Propagation to the explant periphery is indicated by arrows. The large sphere represerts the explant and the small sphere the cell cluster within it.

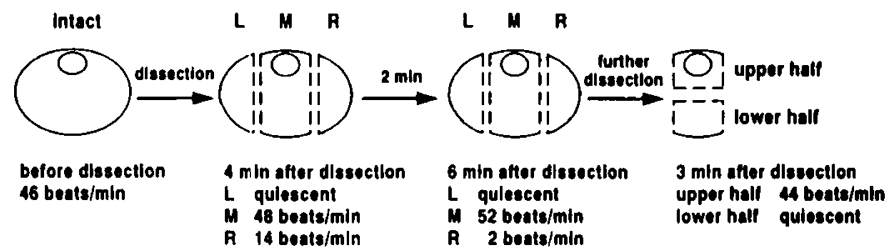

Figure 8. The explant shown in Figure 6 was subdivided into four pieces. Only the piece containing the cluster of cells continued to fire the original rate $( \pm 10 \%)$. The large circle represents the explant and the small circle the cell cluster. Dotted lines represent lines of division. $L, M$, and $R$, left, middle, and right portions of the explant, respectively.

Each cell located in the base of the cluster (Fig. 4, left of center) contained a single multilobed nucleus with irregular margins and clurnps of condensed heterochromatin (enlarged in Fig. 10). The cytoplasm contained numerous free ribosomes and a few small mitochondria. Only a narrow strip of cytoplasm surrounded the nucleus, so the nucleus occupied at least $40 \%$ of the cell area in profile.

Figure 11 illustrates that the majority cell type outside the clusters was of the cardiac myocyte phenotype $(10 \pm 5 \mu \mathrm{m}$ 


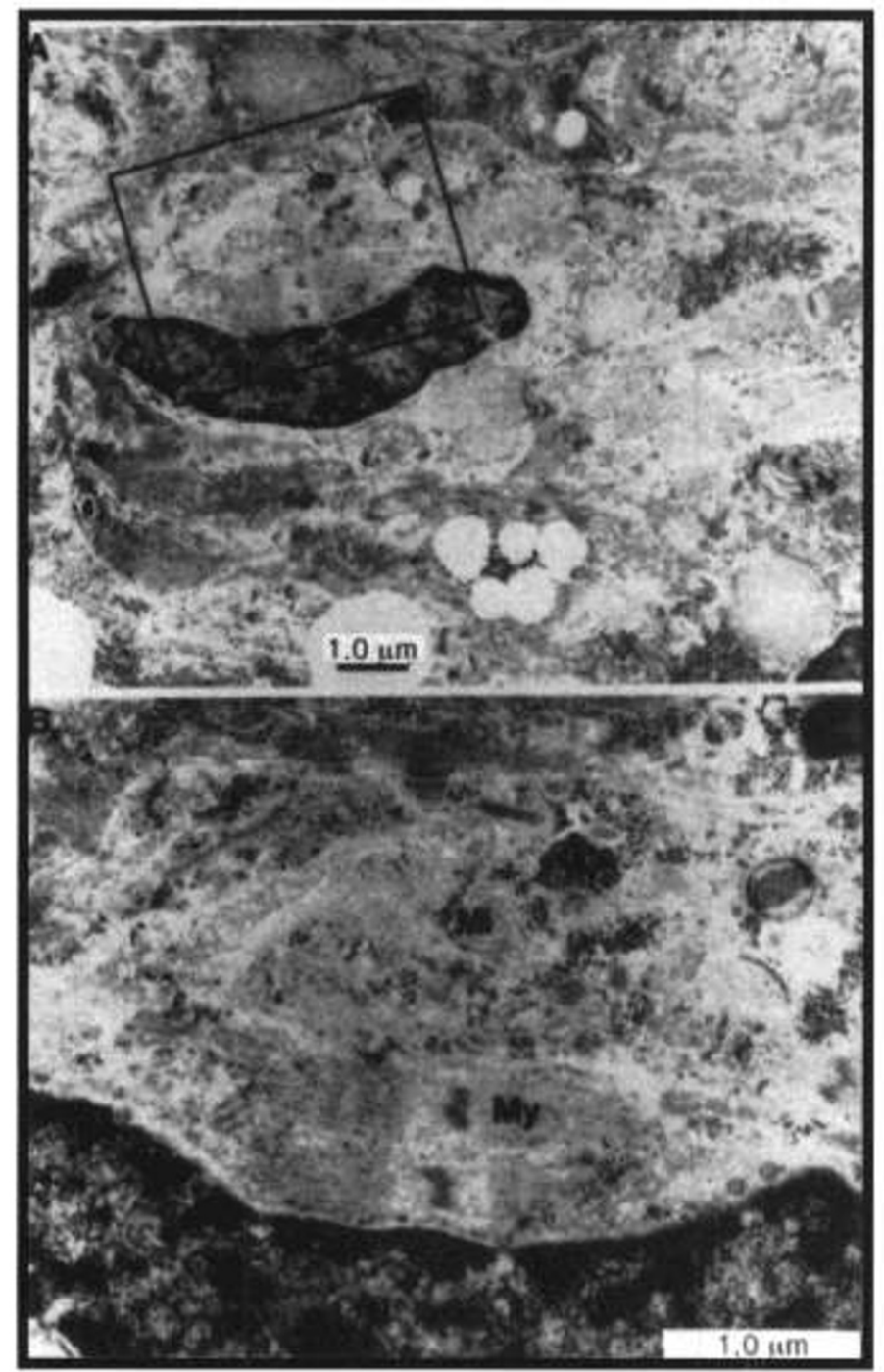

Figure 9. Electron micrograph of a cell from the cluster area. The frame in $A$ outlines the area enlarged in $B$. $G$, glycogen granules; $M i$, mitochondrion; $M y$, myofibril; $N$ nucleus. Bars in $A$ and $B, 1 \mu \mathrm{m}$.

diameter). They contained one central nucleus with condensed heterochromatin. The cytoplasm was packed with bundles of myofibrils lying parallel to the long axis of the cell. Intercellular contacts were undifferentiated membrane appositions with few fasciae adherens and maculae adherens and negligible nexuses.

\section{DISCUSSION}

Previous studies of ventricular explants cultured in oculo suggested that pacemaker regions might be induced by neural, vascular, or epithelial cells of the host tissue (iris or cornea) (3), because pacemakers always organized around the point of vascularization of the implant. The present report does not support that hypothesis, because a similar process of pacemaker genesis was observed in embryonic myocardium devoid of any extrinsic cells contributed by the culture system.

The possibility that pacemaker clusters may be induced by surface contact per se should be considered. Pacemaker clusters were not observed in tubular ventricles before attachment in culture. After contact and attachment to a new growth surface, conditions may have become appropriate to generate a

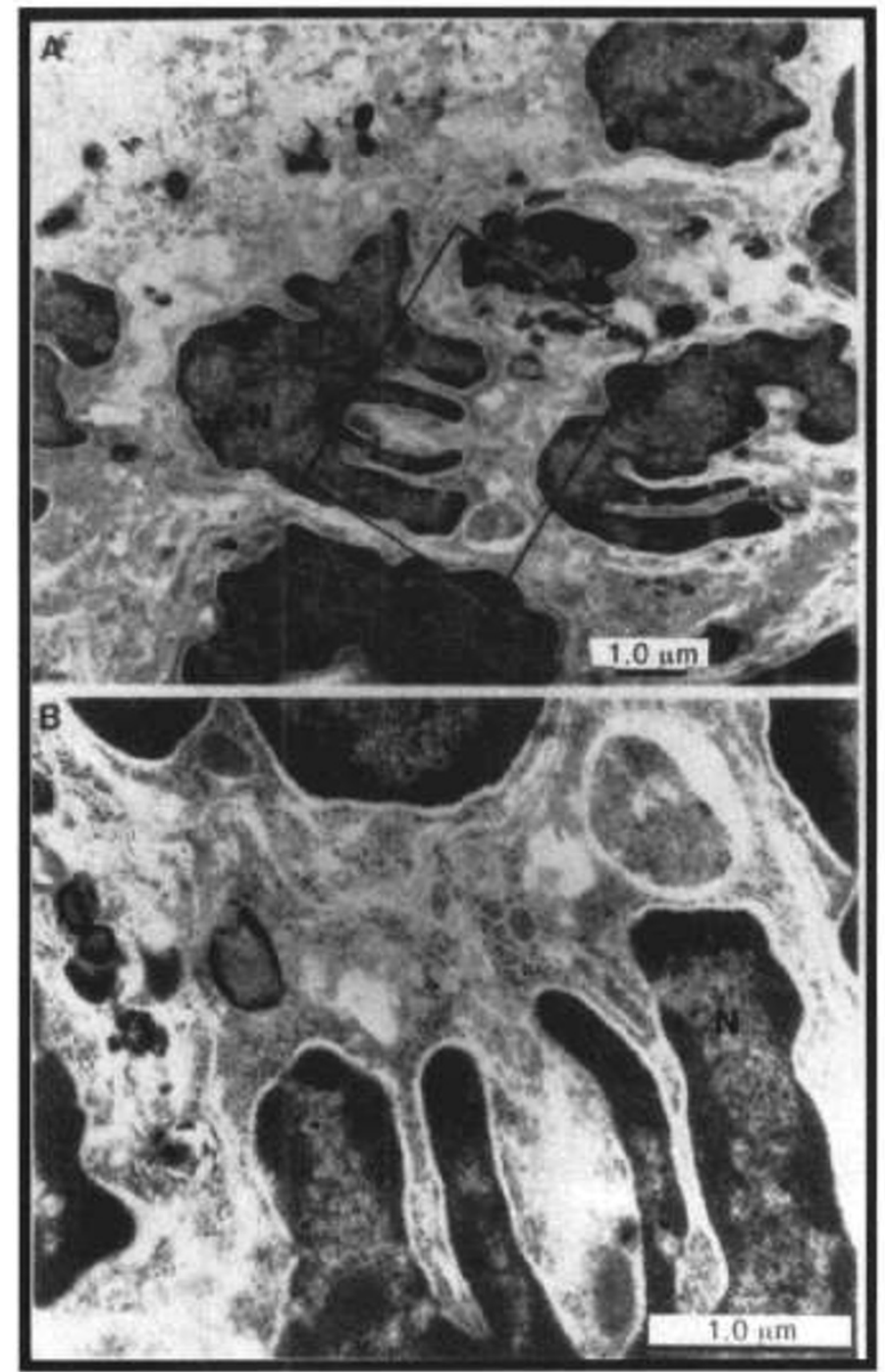

Figure 10. Electron micrograph of a group of cells from the base of the cluster. The frame in $A$ outlines the area enlarged in $B . N$, multilobed nuclei. Bars in $A$ and $B, 1 \mu \mathrm{m}$.

new pacemaker region. Attachment to the culture dish surface may elicit secretion of extracellular matrix or other proteins that facilitate pacemaker formation. Unattached explants, although not always quiescent, never developed pacemakers like those observed in attached explants. The present study was not designed to test the contact induction hypothesis.

Working muscle-type action potentials were recorded only in the myocyte mass surrounding the cluster. Some quantitative differences between these and action potentials of mature rat ventricular myocytes $(1,13)$ can be accounted for by the immature stage of electrophysiologic development and the slowing of development by tissue culture (14-16). The postulated pacemaker function of the cluster was confirmed by the observation that pacemaker action potentials were found there exclusively. Pacemaker precursor cells have been identified in the ventricular primordia of the chick heart (stage 4, 18-19 h of incubation) (17). Transmembrane potentials of all myocardial cells at this developmental stage and later depolarize spontaneously during diastole $(14,18-20)$. As development proceeds, spontaneous depolarization is observed in progres- 


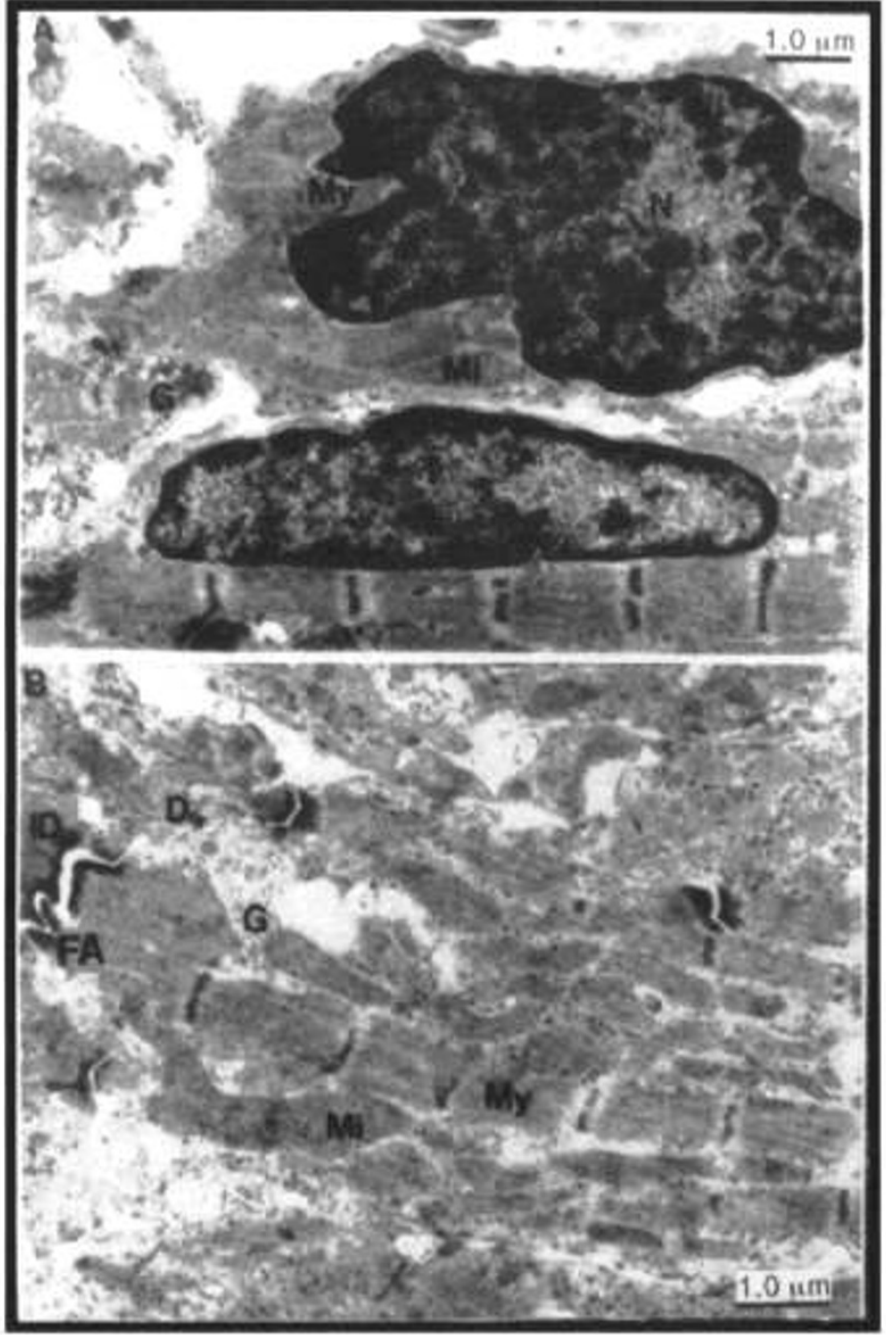

Figure 11. Electron micrograph of cells outside cluster. $D$, macula adherens (desmosome); $F A$, fascia adherens; $G$, glycogen granules; $I D$, intercalated disc; $M i$, mitochondrion; $M y$, myofibril; $N$, nucleus. Bars in $A$ and $B, 1 \mu \mathrm{m}$.

sively fewer myocardial cells $(3,19-21)$. Whether automaticity disappears entirely from developing ventricular cells, and new pacemaker cells arise, or some ventricular cells retain the original ability to fire spontaneously, remains to be demonstrated by future studies.

The cluster contained cells with ultrastructural features (see Fig. 10) similar to atrioventricular node cells and conduction fibers in the ventricle of the rat (22-24). Nuclei of cells at the base (Fig. 4, left) of the cluster were deeply invaginated, suggesting that they may be rapidly proliferating cells (25-30). A relationship between rates of cell division and conduction system development has been proposed (31).

The walls of staged (32) primitive tubular hearts contain the splanchnic mesoderm-derived $(33,34)$ precursors for myocardial cells and pacemaker cells [chick (35) and ferret (36)], and, based on morphologic criteria, only the myocardial cell type has been observed. Results of the present study suggest that, if some of the myocardial cells at this stage are already committed to a pacemaker phenotype, their morphology does not reveal it. Contact with a noncardiac surface in culture might cause some of the myocardial cells to convert to the pacemaker phenotype permanently.

\section{REFERENCES}

1. Davies MJ, Anderson RH, Becker AE 1983 Embryology of the conduction tissues. In: Davies MJ, Anderson RH, Becker AE (eds) The Conduction System of the Heart. Butterworths, Boston, pp 81-94

2. DeHaan RL 1965 Development of pacemaker tissue in the embryonic heart. Ann NY Acad Sci 127:7-18

3. Tucker DC, Snider C, Woods WT Jr 1988 Pacemaker development in embryonic rat heart cultured in oculo. Pediatr Res 23:637-642

4. Armiger LC, Wcods WT Jr, Tucker DC 1992 Morphological development of the cardiac pacemaker in embryonic rat atria grown in oculo. J Mol Cell Cardiol 24:S-196

5. Sperelakis N, Shigenobu K 1974 Organ-cultured chick embryonic hearts of various ages. 1. Electrophysiology. J Mol Cell Cardiol 6:449-471

6. Freshney RI 1983 The culture environment: I. Substrate, gas phase, and temperature. In: Freshney RI (ed) Culture of Animal Cells. Alan R Liss, New York, pp 55-66

7. Yamada KM 1983 Cell surface interactions with extracellular materials. Annu Rev Biochem 52:761-799

8. Woods WT, Urthaler F, James TN 1976 Spontaneous action potentials of cells in the canine sinus node. Circ Res 39:76-82

9. Woods WT, Sherf L, James TN 1982 Structure and function of specific regions in the canine atrioventricular node. Am J Physiol 243:H41-H52

10. Spurr AR 1969 A low-viscosity epoxy resin embedding medium for electron microcopy. J Ultrastruct Res 26:31-43

11. Reynolds BS $196: 3$ The use of lead citrate at high $\mathrm{pH}$ as an electron-opaque stain in electron microscopy. J Cell Biol 17:208-212

12. Lentz TL 1971 Skin and other epithelia, and vascular tissue. In: Lentz TJ (ed) Cell Fine Structure. WB Saunders, Philadelphia, pp 103-148

13. Hoffman BF, Cranefield PF 1976 Electrophysiology of the Heart. Futura Publishing, New York, p 323

14. Bernard C. Establithment of ionic permeabilities of the myocardial membrane during embryonic development of the rat. In: Lieberman M, Sano T (eds) Developmental and Physiological Correlates of Cardiac Muscle. Raven Press, New York, pp 169-184

15. Sperelakis $\mathbf{N} 1982$ Pacemaker mechanisms in myocardial cells during development of embryonic chick tearts. In: Bouman LN, Jongsma HJ (eds) Cardiac Rate and Rhythm. Martinus Nijhoff Publishers, The Hague, pp 129-165

16. Sperelakis $\mathbf{N} 1989$ Developmental changes in membrane electrical properties of the heart. In: Sperelakıs N (ed) Physiology and Pathophysiology of the Heart, 2nd Ed. Kluwer Academic Publishers, Boston, pp 595-623

17. DeHaan RL 1963 Regional organization of pre-pacemaker cells in the cardiac primordia of the early chick embryo. J Embryol Exp Morphol 11:65-76

18. Couch JR, West TC, Hoff HE 1969 Development of the action potential of the prenatal rat heart. Circ Res 24:19-31

19. Sperelakis N, Shigenobu K 1972 Changes in membrane properties of chick embryonic hearts during development. J Gen Physiol 60:430-453

20. Sperelakis N, McLvan MJ 1978 The electrical properties of embryonic chick cardiac cells. In: Longo LI), Renaud DD (eds) Fetal and Newborn Cardiovascular Physiology, Vol 1. Garland Press, New York, pp 191-236

21. Cavanaugh MW 1955 Pulsation, migration and division in dissociated chick embryo heart cells in vitro. J Exp Zool 128:573-589

22. Mochet M, Moravec J, Guillemot H, Hatt PY 1975 The ultrastructure of rat conductive tissue: an electron microscopic study of the atrioventricular node and the bundle of His. J Mol Cell Cardiol 7:879-889

23. Truex RC, Smythe MQ 1965 Comparative morphology of the cardiac conduction tissue in animals. Ann NY Acad Sci 127:19-33

24. Melax H, Leeson TS 1970 Fine structure of the impulse-conducting system in rat heart. Can J Zool 4:3:837-839

25. Haguenau F 1969 Litrastructure of the cancer cell. In: Bittar EE. Bittar N (eds) The Biological Basis of Medicine, Vol 5. Academic Press, New York, pp 433-486

26. Blackburn WR 1971 Pathobiology of nucleocytoplasmic exchange. Pathobiol Ann 1:1-31

27. Weber AF 1974 Nuclear pockets in blood leukocytes, a morphological marker of possible early diagnostic value for lymphocyte leukaemia. Schweiz Med Wochenschr $104: 284-286$

28. Trump BF, Jesudascon ML, Jones RT 1978 Ultrastructural features of diseased cells. In: Trump BF, Jones RT (eds) Diagnostic Electron Microscopy, Vol I. John Wiley \& Sons, New York, pF 1-88

29. Ghadially FN 1980 Diagnostic Electron Microscopy of Tumors. Butterworths, Boston, $\mathrm{p} 251$

30. Ghadially FN 1982 Ultrastructural Pathology of the Cell and Matrix: A Text and Atlas of Physiological anc Pathological Alterations in the Fine Structure of Cellular and Extracellular Components. Butterworths, Boston, p 971

31. Thompson RP, Lindroth JR, Wong Y-MM 1990) Regional differences in DNAsynthetic activity in the preseptation myocardium of the chick. In: Clark EB, Takao A (eds) Developmental Cardiology: Morphogenesis and Function. Futura, Mount Kisco, NY, pp 219-234

32. Manasek FJ 1979 Organization, interactions, and environment of heart cells during myocardial ontogeny. In: Berne RM, Sperelakis N, Geiger SR (eds) Handbook of Physiology, Sect 2. The Cardiovascular System, Vol 1. The Heart. Williams \& Wilkins, Baltimore, pp 29-42

33. Baldwin HS, Jenser KL. Solursh M 1991 Myogenic cytodifferentiation of the precardiac mesoderm in the rat. Differentiation 47:163-172

34. Hamburger V, Hamilton JL 1951 A series of normal stages in the development of the chick embryo. J Morphol 88:49-92

35. Marino TA, Severdia JB 1982 Fine structural examination of the single heart tube in the fifteen day ferret embryo. Cell Tissue Res 221:597-605

36. Manasek MJ 1970 Histogenesis of the embryonic myocardium. Am J Cardiol 25:149-168 